\title{
Perancangan Alat Ukur Digital untuk Tinggi dan Berat Badan dengan Output Suara berbasis Arduino UNO
}

\author{
MUHAMMAD AFDALI, MUHAMMAD DAUD, RAIHAN PUTRI \\ Jurusan Teknik Elektro, FakultasTeknik, Universitas Malikussaleh \\ Email: syekhafdal@gmail.com
}

\begin{abstract}
ABSTRAK
Alat pengukur tinggi badan dan penimbang berat badan yang sekaligus memberikan informasi berat badan ideal akan sangat bermanfaat bagi para pengguna. Oleh karena itu, dalam penelitian ini, dirancang dan direalisasikan suatu alat ukur yang sekaligus dapat mengukur tinggi badan dan berat badan serta memberikan informasi ideal atau tidaknya berat badan yang terukur. Alat ukur ini menggunakan Arduino Uno sebagai otaknya, sensor ultrasonik untuk mengukur tinggi badan, dan sensor strain gauge untuk mengukur berat badan. Data dari kedua sensor tersebut diolah oleh Arduino untuk mendapatkan indeks massa tubuh (IMT) dan berat badan ideal (BBI). Nilai tinggi badan, berat badan, dan berat badan ideal akan ditampilkan pada LCD. Selanjutnya, informasi suara menyangkut kondisi berat badan yaitu ideal, gemuk, atau kurus akan dikeluarkan oleh speaker. Berdasarkan hasil pengujian dan analisis data maka diperoleh nilai persentase keberhasilan rata-rata pada pengukuran tinggi badan adalah 96,80\% dan pada pengukuran berat badan adalah 99,04\%. Sedangkan tingkat keberhasilan penampilan informasi suara adalah 95\%.
\end{abstract}

Kata kunci: Alat ukur digital, tinggi badan, berat badan, Arduino, output suara.

\begin{abstract}
An instument for measuring height and weight while providing information ideal weight for users will be very helpful. Therefore, in this study, it was designed and realized a measuring instrument which can simultaneously measure the height and weight as well as providing the ideal information whether or not the weight measured. This instrument uses an Arduino Uno as the brain, the ultrasonic sensor to measure the height and strain gauge sensor for measuring weight. Data from the sensors is processed by the Arduino to get a body mass index and ideal weight. The values of height, weight, and ideal weights will display on LCD. Furthermore, voice information regarding the ideal conditions of weight, namely ideal, fat, or thin will be emitted by a speaker. Based on test results and data analysis, obtained that values of the average percentage of success at the height measurement was $96.80 \%$ and the weight measurement was $99.04 \%$, respectively. While the success rate of emitting the sound information is $95 \%$.
\end{abstract}

Keywords: Digital measuring instrument, height, weight, Arduino, sound output. 


\section{PENDAhULUAN}

Hampir setiap orang mendambakan berat badan ideal, karena ini merupakan hal yang bagus, baik dari segi penampilan fisik maupun dari segi kesehatan. Terutama kaum muda lebih banyak yang mendambakannya karena dengan berat yang ideal penampilan fisik akan menjadi lebih menarik (Thomas, dkk, 2015). Berbagai cara dilakukan orang agar dapat mencapai berat badan yang ideal mulai dari mengatur pola makan, diet ketat, berolahraga yang teratur sampai dengan meminum obat-obatan (Khoiruddin, 2015).

Sering kali dijumpai di tempat-tempat seperti rumah sakit, apotik, dan sanggar kebugaran bahwa alat pengukur tinggi dan berat badan masih dioperasikan secara manual dan terpisah, sehingga sulit untuk mengetahui apakah berat badannya telah ideal atau belum. Umumnya masyarakat masih banyak yang belum mengetahui berapa berat badan yang sesuai untuk dirinya dan hanya menerka-nerka saja atau melihat sebatas pandangannya hasil pengukuran berat badannya (Thomas, dkk, 2015).

Upaya untuk membuat alat pengukur berat badan sekaligus tinggi badan telah dilakukan oleh beberapa peneliti, diantaranya Fadli (Fadli, 2013) yang merancang dan membangun alat pengukur berat dan tinggi badan ideal berbasis mikrokontroler. Kemudian Thomas dkk (Thomas, dkk, 2015) juga mengembangkan sistem pengukur berat dan tinggi badan yang menggunakan mikrokontroler AT89S51. Selanjutnya, juga ada penelitian untuk pengembangan alat ukur tinggi badan dan berat badan digital yang terintegrasi (Khoiruddin, 2015).

Namun, beberapa rancangan alat ukur dalam penelitian-penelitian tersebut hanya menampilkan hasil pengukuran dalam bentuk tulisan pada LCD. Padahal jika hasil pengukurannya juga dapat disajikan dalam bentuk suara tentu akan lebih memberikan kemudahan dan kenyamanan bagi pengguna. Oleh karena itu, dalam penelitian ini dikembangkan alat ukur tinggi badan dan berat badan yang hasil pengukurannya serta informasi ideal atau tidaknya berat badan tersebut disajikan dalam bentuk tulisan pada LCD dan juga dalam bentuk suara pada speaker. Dengan demikian, pengukuran tinggi dan berat badan menjadi lebih mudah, cepat, praktis, dan akurat serta lengkap dengan informasi berat badan idealnya.

\subsection{Perhitungan Berat Badan Ideal Berdasarkan Indeks Massa Tubuh (IMT)}

Mengukur berat badan ideal dengan indeks massa tubuh (IMT) ini merupakan cara yang paling banyak atau paling umum dilakukan orang. Caranya, berat badan yang terukur dalam satuan kilogram dibagi dengan tinggi badannya dalam satuan meter yang sebelumnya sudah dikuadratkan. Batas ambang IMT ditentukan dengan merujuk ketentuan FAO atau WHO. Untuk kepentingan Indonesia, batas ambang dimodifikasi berdasarkan pengalaman klinis dan hasil penelitian di beberapa negara berkembang. Adapun rumus perhitungan IMT adalah menggunakan Persamaan 1 di bawah ini (Erlita, 2015).

$$
I M T=\frac{B B}{(T B)^{2}}
$$

dimana IMT adalah indeks masa tubuh, $B B$ adalah berat badan $(\mathrm{kg})$, dan $T B$ adalah tinggi badan (m). Adapun untuk mencari batas ambang berat badan ideal (BBI) adalah dengan menggunakan Persamaan 2 dan 3 berikut ini.

$$
B A B=18 \times(\mathrm{TB})^{2}
$$




$$
B A A=25 \times(\mathrm{TB})^{2}
$$

dimana $B A B$ adalah batas ambang bawah dan $B A A$ adalah batas ambang atas. Kemudian pengelompokan ideal (normal), kurus, ataupun gemuk mengikuti Tabel 1 berikut ini.

Tabel 1. Klasifikasi BMI/IMT menurut WHO (Fadli, 2013)

\begin{tabular}{|c|c|}
\hline Klasifikasi & Nilai IMT \\
\hline Kurus (Underweight) & $<18$ \\
\hline Normal (Idea) & $18-25$ \\
\hline Gemuk (Overweight) & $>25$ \\
\hline
\end{tabular}

\subsection{Sensor Ultrasonik}

Sensor ultrasonik terdiri dari sebuah chip pembangkit sinyal $40 \mathrm{KHz}$, sebuah speaker ultrasonik, dan sebuah mikropon ultrasonik. Speaker ultrasonik mengubah sinyal $40 \mathrm{KHz}$ menjadi suara sedangkan mikropon ultrasonik berfungsi untuk mendeteksi pantulan suaranya. Sensor ultrasonik adalah sensor yang bekerja berdasarkan prinsip pantulan gelombang suara dan digunakan untuk mendeteksi keberadaan suatu objek tertentu di depannya. Frekuensi kerjanya adalah pada daerah di atas gelombang suara dari $40 \mathrm{KHz}$ hingga $400 \mathrm{KHz}$ (Khoiruddin, 2015). Cara kerja sensor ultra dapat diilustrasikan seperti pada Gambar 1 di bawah ini.

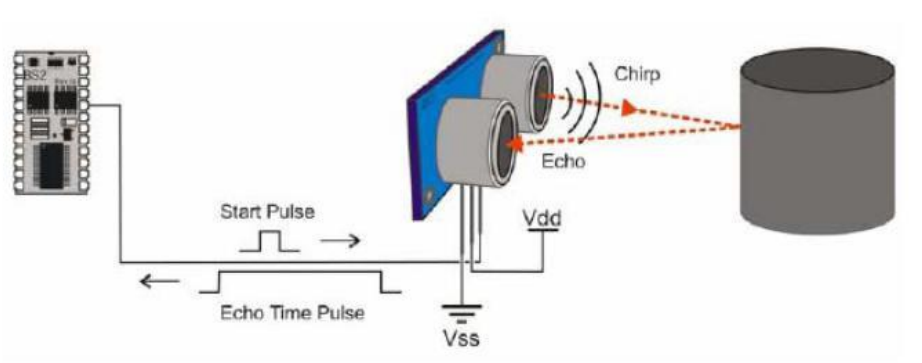

Gambar 1. Cara kerja sensor ultrasonik

Apabila sensor ultrasonik digunakan untuk mengukur tinggi badan maka perhitungannya adalah menggunakan rumus pada persamaan 4 dan 5 berikut ini (Erlita, 2015). Dengan asumsi bahwa sensor diletakkan pada ketinggian $200 \mathrm{~cm}$, maka

$$
\begin{gathered}
T B=200-L \\
L=(I p / 29 \mu \mathrm{s}) / 2
\end{gathered}
$$

Dimana angka 200 adalah jarak sensor dengan lantai, TB adalah tinggi badan, $L=$ jarak sensor dengan permukaan kepala, $I p=$ lebar pulsa jarak dalam satuan mikro sekon ( $\mu \mathrm{s})$ dalam satu kali pemantulan.

\subsection{Arduino}

Arduino adalah kit elektronik atau papan rangkaian elektronik open source yang didalamnya terdapat komponen utama yaitu sebuah chip mikrokontroler dengan jenis AVR dari perusahaan Atmel. Mikrokontroler itu sendiri adalah chip atau integrated circuit (IC) yang bisa diprogram menggunakan komputer (Utama, dkk, 2008). Jenis Arduino yang digunakan dalam penelitian ini adalah Arduino Uno, seperti disajikan pada Gambar 4 di bawah ini. 


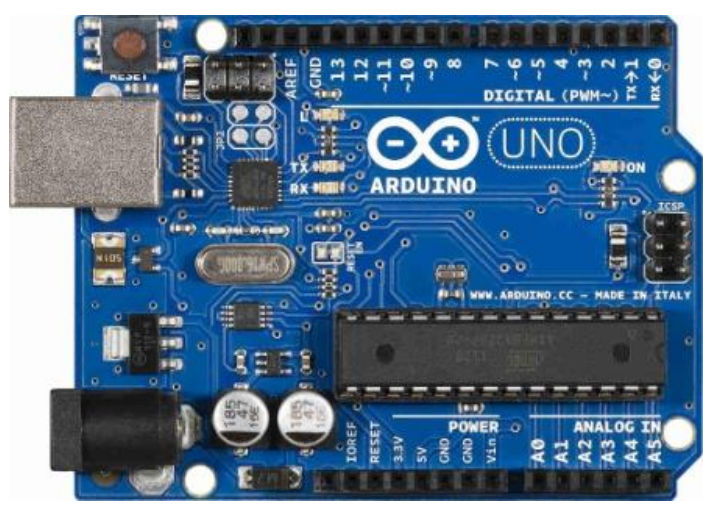

\section{Gambar 2. Papan (board) Arduino Uno}

\subsection{Information Storage Device (ISD) 1760}

Information storage device (ISD) 1760 adalah sebuah IC yang dapat menyimpan atau mengeluarkan pesan yang terekam dengan metode pengalamatan (Nuryanto, 2015). ISD merupakan suatu chip IC yang bila terintegrasi terhadap komponen pendukung bias digunakan sebagai penyimpanan data suara yang direkam dan didowloadkan ke dalamnya dengan durasi rekam atau putar (record or playback) antara 60 sampai dengan 120 detik (Fadli, 2013). Rangkaian IC ISD 1760 yang digunakan dalam penelitian ini ditunjukkan pada Gambar 3 di bawah ini.

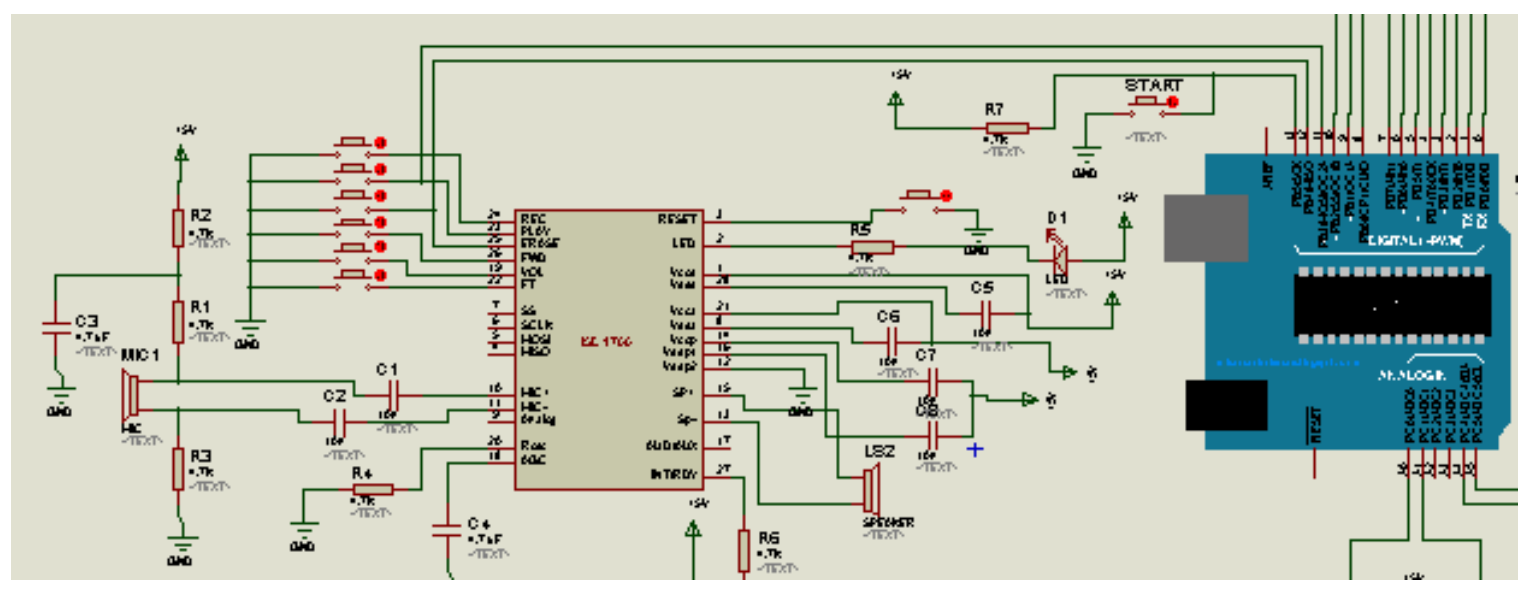

Gambar 3. Rangkaian IC ISD 1760

\subsection{Speaker}

Speaker adalah transduser yang mengubah sinyal elektrik ke frekuensi audio (suara) dengan cara menggetarkan komponennya yang berbentuk membran untuk menggetarkan udara sehingga terjadilah gelombang suara. Salah satu contoh speaker ditunjukkan dalam Gambar 4 berikut ini.

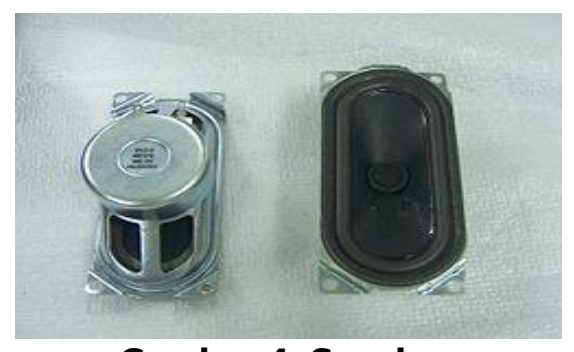

Gambar 4. Speaker 


\subsection{Sensor Strain Gauge (Load cell)}

Load cell adalah komponen utama pada sistem timbangan digital, dimana tingkat keakurasian timbangannya bergantung dari jenis load cell yang dipakai. Sensor load cell apabila diberi beban pada inti besi maka nilai resistansi pada strain gaugenya akan berubah yang dikeluarkan melalui tiga buah kabel, dimana dua kabel sebagai eksitasi dan satu kabelnya lagi sebagai sinyal keluaran ke kontrolnya. Sebuah load cell terdiri dari konduktor, strain gauge, dan jembatan wheatstone (Nuryanto, 2015). Contoh load cell dapat ditunjukkan pada Gambar 5 berikut ini.

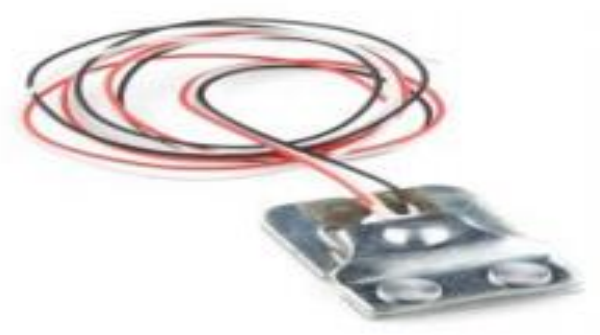

Gambar 5. Sensor load cell

\subsection{Modul HX711}

HX711 adalah modul timbangan yang memiliki prinsip kerja menguatkan perubahan tegangan yang terukur pada sensor load cell dan mengkonversinya ke dalam besaran listrik melalui rangkaian yang ada. HX711 presisi 24-bit analog-to-digital converter (ADC) (Khakim, 2015). Maka perhitungan algoritma ini menggunakan perumusan sebagai berikut

$$
B B=(8407 \times S) \times 102+2400: 1000
$$

Dimana $B B$ adalah berat badan, $S$ adalah nilai input ADC yang terbaca sensor, 8407 adalah nilai beban dalam satuan gram digunakan untuk mengkalibrasi, 102 dan 2400 adalah nilai yang dibaca saat sensor mengukur berat 8407, dan 1000 adalah nilai pembagian untuk menjadikan $\mathrm{kg}$.

\section{METODOLOGI PENELITIAN}

Pada penelitian ini membahas tentang perancangan dan pembuatan alat pengukur tinggi dan berat badan secara ideal dengan output suara. Perancangan sistem ini meliputi perancangan perangkat keras (hardware) dan perangkat lunak (software).

\subsection{Blok Diagram Sistem}

Blok diagram sistem merupakan salah satu bagian terpenting dalam perancangan dan pembuatan alat ini, karena dari diagram blok dapat diketahui prinsip kerja keseluruhan rangkaian sistem. Diagram blok sistem ditunjukkan dalam Gambar 6 berikut ini. 


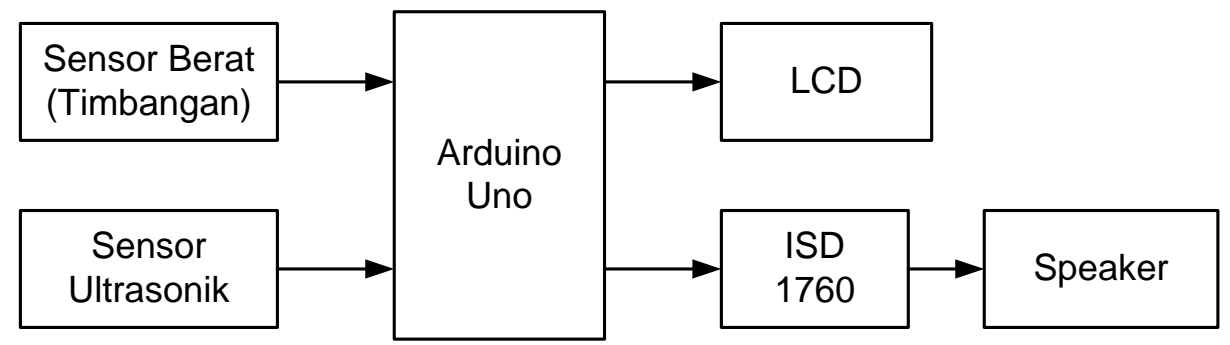

Gambar 6. Blok diagram alat ukur tinggi dan berat badan ideal

\subsection{Rancangan Mekanis Alat Ukur}

Pada perancangan alat ukur tinggi dan berat badan dirancang lebih sederhana sehingga memudahkan waktu pemakaian. Untuk mengukur berat badan dengan berat maksimum 150 kilogram sedangkan untuk mengukur tinggi dengan batasan maksimum 2 meter. Ini dengan pertimbangan bahwa ukuran tinggi badan manusia umumnya lebih kurang dari 2 meter. Dimensi dari rangka alat ukur tinggi dan badan yang dirancang dan dibangun dalam penelitian ini dapat dilihat pada Gambar 7 berikut ini.

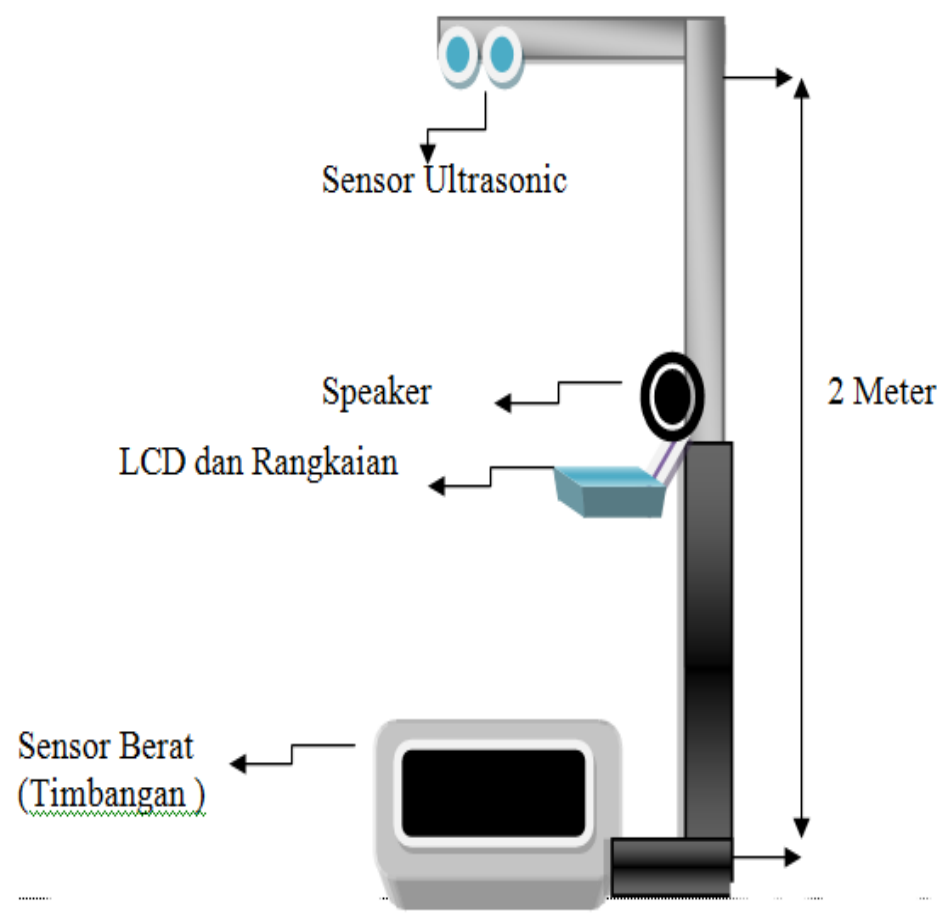

Gambar 7. Rancangan alat pengukur tinggi dan berat badan

\subsection{Diagram Alir Algoritma Alat Ukur}

Rancangan perangkat lunak yang berfungsi untuk mengatur kinerja keseluruhan dari sistem yang terdiri dari beberapa perangkat keras sehingga sistem ini dapat bekerja dengan baik. Diagram alir program utama ditunjukkan dalam Gambar 8. 


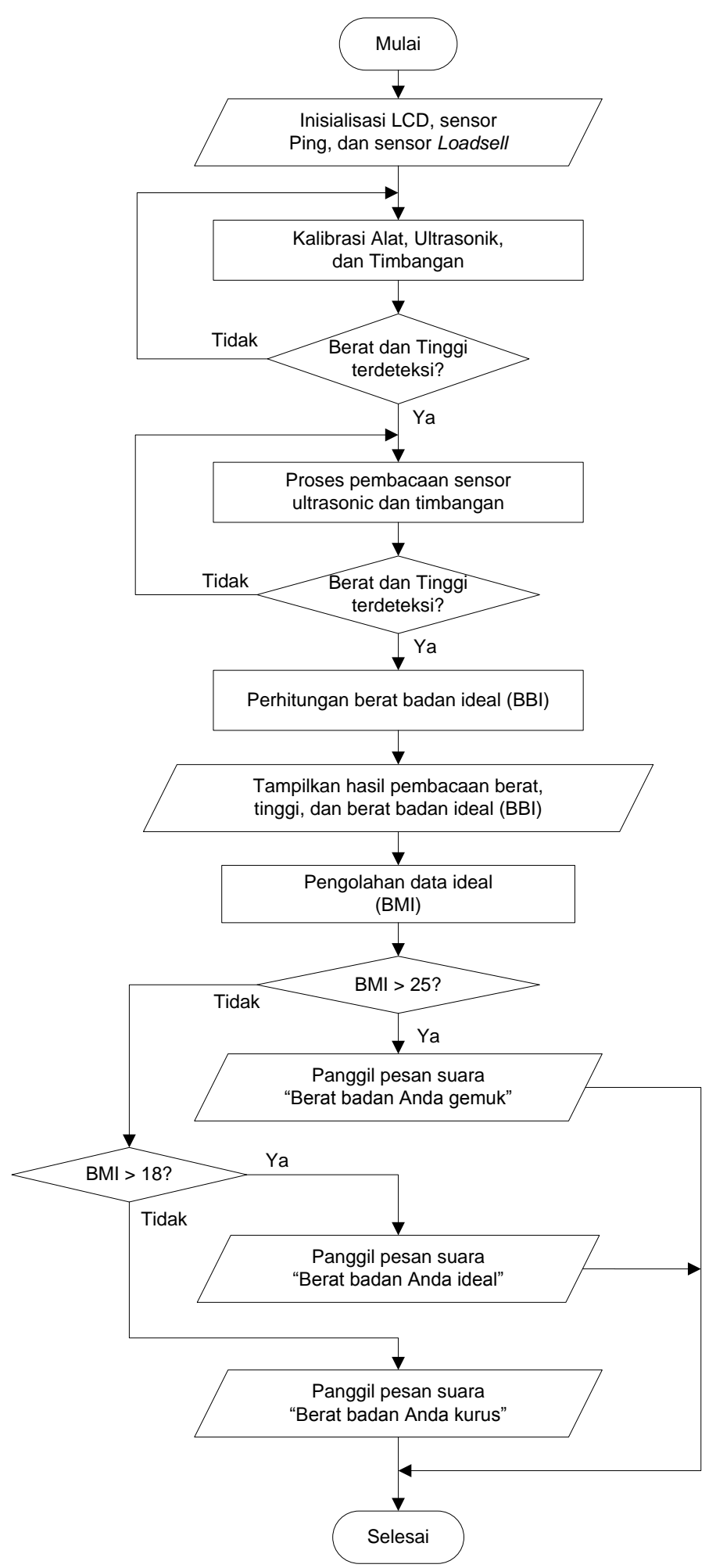

Gambar 8. Diagram alir algoritma alat ukur

\subsection{Realisasi Alat}

Berdasarkan hasil perancangan di atas maka direalisasikan alat ukur digital untuk tinggi dan berat badan dengan output suara berbasis Arduino Uno. Tampilan rangka alat ukur dan tampilan LCD dapat ditunjukkan pada Gambar 9 dan 10 berikut ini. 


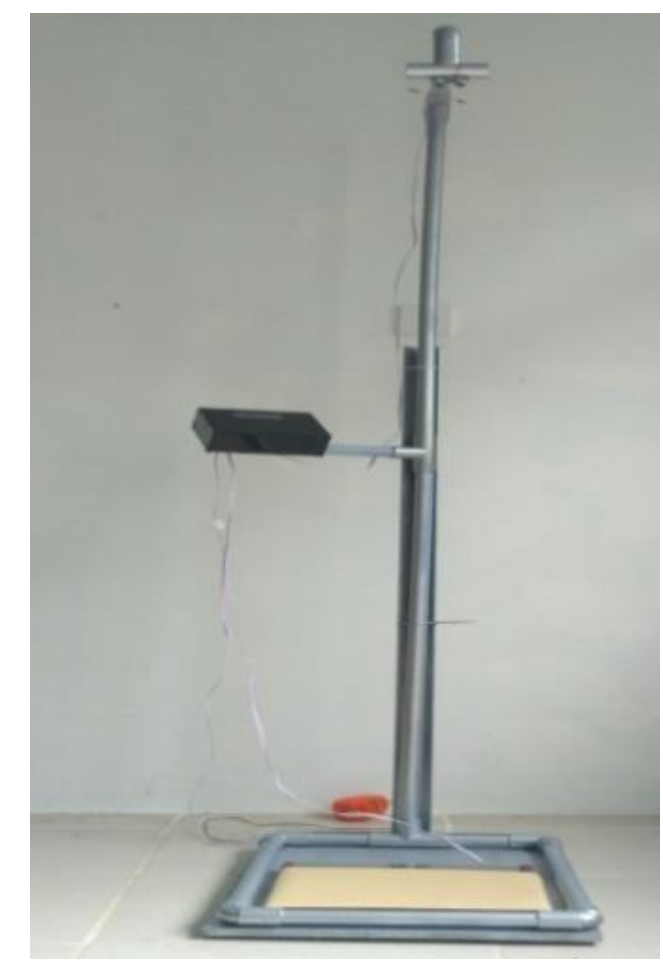

Gambar 9. Alat ukur tinggi dan berat badan ideal (realisasi)

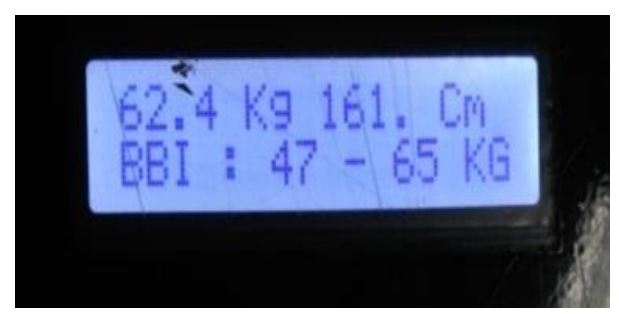

\section{Gambar 10. Tampilan layar LCD pada saat pengukuran}

\subsection{Pengujian Ketelitian}

Berikut ini skema pengujian ketelitian alat yang direalisasikan. Setelah diperoleh data dari pengujian, maka langkah selanjutnya adalah menganalisa data tersebut dan melakukan perhitungan analisis nilai persentase (\%) keberhasilan dan persentase (\%) kesalahan (error) pada alat ukur tinggi dan berat badan tersebut. Rumus-rumus pencarian persentase kesalahan dan keberhasilan adalah berdasarkan Persamaan 7 - 10 berikut ini (Lukman, 2015).

$$
\begin{gathered}
\text { Persentase keberhasilan }=\frac{\text { Terbaca }}{\text { Aktual }} \times 100 \% \\
\text { Persentase kesalahan }=\frac{\text { Aktual }- \text { Terbaca }}{\text { Aktual }} \times 100 \% \\
\text { Persentase kesalahan }=100 \%-\text { Persentase keberhasilan } \\
\text { Rata-rata }=\frac{n}{N} \times 100 \%
\end{gathered}
$$


Berdasarkan pencarian persentase error dan keberhasilan maka range persentase dan kriteria kualitatif dapat ditetapkan pada Tabel 2 berikut ini.

Tabel 2. Range persentase dan kriteria kelayakan (Lukman, 2015)

\begin{tabular}{|c|c|}
\hline Skor dalam persentase & Kriteria \\
\hline $80 \%<$ persentase $\leq 100 \%$ & Sangat Baik \\
\hline $60 \%<$ persentase $\leq 80 \%$ & Baik \\
\hline $40 \%<$ persentase $\leq 60 \%$ & Cukup Baik \\
\hline $20 \%<$ persentase $\leq 40 \%$ & Kurang Baik \\
\hline $0 \% \leq$ persentase $\leq 20 \%$ & Tidak Baik \\
\hline
\end{tabular}

\section{HASIL PENGUJIAN DAN PEMBAHASAN}

\subsection{Pengujian Sistem Pengukur Tinggi Badan}

Pengujian sistem pengukuran tinggi badan dilakukan dengan membandingkan pengukuran tinggi badan menggunakan alat (modul) hasil perancangan terhadap pengukuran tinggi badan secara konvensional yang menggunakan sebuah meteran. Hasil pengujian tersebut ditunjukkan pada Tabel 3 berikut ini.

Tabel 3. Hasil pengujian pengukuran tinggi badan (TB)

\begin{tabular}{|c|c|c|c|c|c|}
\hline No. & Nama & $\begin{array}{c}\text { TB } \\
\text { Konvensional } \\
\mathbf{( c m )}\end{array}$ & $\begin{array}{c}\text { TB } \\
\text { Modul } \\
\mathbf{( c m})\end{array}$ & $\begin{array}{c}\text { Persentase } \\
\text { Keberhasilan } \\
\mathbf{( \% )}\end{array}$ & $\begin{array}{c}\text { Persentase } \\
\text { Error } \\
\mathbf{( \% )}\end{array}$ \\
\hline 1 & Zaki & 165 & 160 & 96,97 & 3,03 \\
\hline 2 & Rizki & 160 & 158 & 98,75 & 1,25 \\
\hline 3 & Sri & 159 & 152 & 95,60 & 4,40 \\
\hline 4 & Ayu & 154 & 150 & 9740 & 2,60 \\
\hline 5 & Mira & 160 & 156 & 97,50 & 2,50 \\
\hline 6 & Fatin & 156 & 150 & 96,15 & 3,85 \\
\hline 7 & Ikhsan & 168 & 160 & 95,24 & 4,76 \\
\hline 8 & Shakir & 170 & 165 & 97,06 & 2,94 \\
\hline 9 & Shadri & 178 & 171 & 96,07 & 3,93 \\
\hline 10 & Maulana & 170 & 168 & 98,82 & 1,18 \\
\hline 11 & Imam & 166 & 159 & 95,78 & 4,22 \\
\hline 12 & Ali & 169 & 164 & 97,04 & 2.96 \\
\hline 13 & Maulid & 179 & 171 & 95,53 & 4,47 \\
\hline 14 & Naina & 155 & 149 & 96,13 & 3,87 \\
\hline 15 & Kamal & 171 & 168 & 98,25 & 1,75 \\
\hline 16 & Irma & 153 & 149 & 97,39 & 2,61 \\
\hline 17 & Diara & 160 & 154 & 96,25 & 3,75 \\
\hline 18 & Wanda & 159 & 154 & 96,86 & 3,14 \\
\hline 19 & Rafai & 156 & 149 & 95,51 & 4,49 \\
\hline 20 & Afdali & 170 & 166 & 97,65 & 2,35 \\
\hline Selisih rata-rata persentase keberhasilan dan error & 96,80 & 3,20 \\
\hline
\end{tabular}

Jadi berdasarkan hasil yang didapatkan pada pengukuran yang ditunjukkan pada Tabel 3, maka diperoleh grafik data seperti pada Gambar 11. 


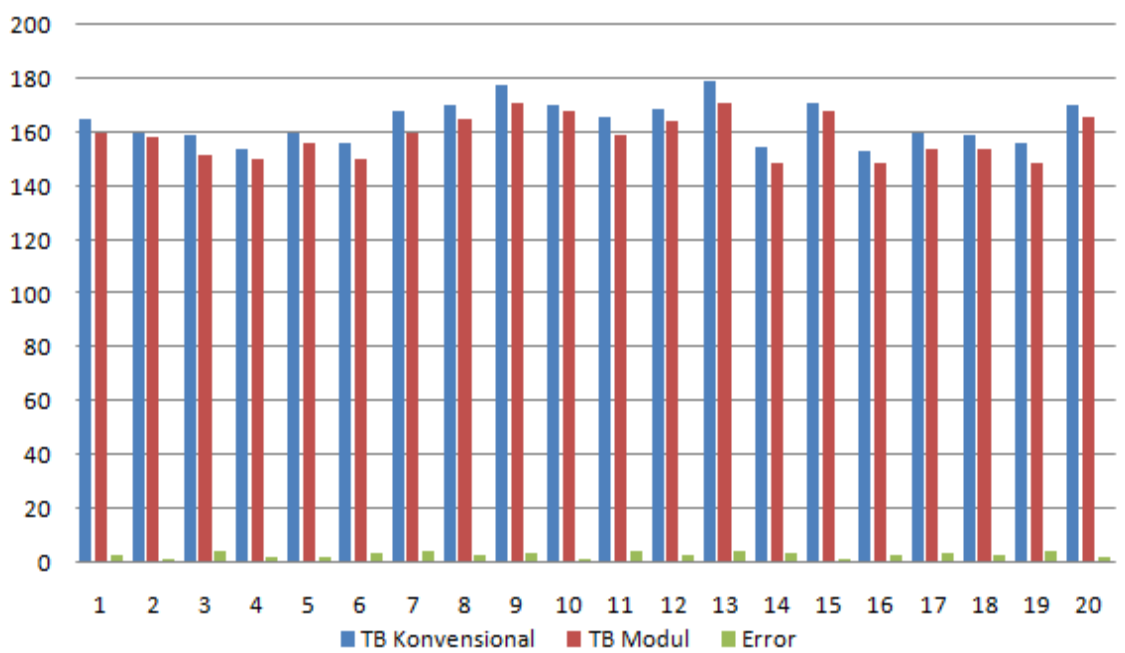

Gambar 11. Grafik data pengukuran tinggi badan

\subsection{Pengujian Sistem Pengukur Berat Badan}

Adapun pengujian sistem pengukuran berat badan dilakukan dengan membandingkan hasil pengukuran menggunakan alat (modul) hasil perancangan terhadap hasil pengukuran berat badan menggunakan sebuah timbangan digital konvensional. Kedua hasil pengukuran berat badan tersebut ditunjukkan pada Tabel 4 di bawah ini.

Tabel 4. Hasil pengujian pengukuran berat badan (BB)

\begin{tabular}{|c|c|c|c|c|c|}
\hline No. & Nama & $\begin{array}{c}\text { Timbangan } \\
\text { Konvensional } \\
(\mathbf{k g})\end{array}$ & $\begin{array}{c}\text { Timbangan } \\
\text { Modul } \\
\text { (kg) }\end{array}$ & $\begin{array}{c}\text { Persentase } \\
\text { Keberhasilan } \\
(\%)\end{array}$ & $\begin{array}{c}\text { Persentase } \\
\text { Error } \\
(\%)\end{array}$ \\
\hline 1 & Zaki & 64,5 & 65,2 & 98,93 & 1,07 \\
\hline 2 & Rizki & 40 & 40,7 & 98,28 & 1,72 \\
\hline 3 & Sri & 49,6 & 50 & 99,20 & 0,80 \\
\hline 4 & Ayu & 60,7 & 61,4 & 98,86 & 1,14 \\
\hline 5 & Mira & 52.5 & 53,2 & 98,68 & 1,32 \\
\hline 6 & Fatin & 71,8 & 72,6 & 98,90 & 1,10 \\
\hline 7 & Ikhsan & 80,1 & 80,8 & 99,13 & 0,87 \\
\hline 8 & Shakir & 65,7 & 66,3 & 99,10 & 0,90 \\
\hline 9 & Shadri & 60,9 & 61,3 & 99,35 & 0,65 \\
\hline 10 & Maulana & 57,7 & 58,1 & 99,31 & 0,69 \\
\hline 11 & Imam & 90 & 91,4 & 98,47 & 1,53 \\
\hline 12 & Ali & 68,8 & 69,1 & 99,57 & 0,43 \\
\hline 13 & Maulid & 66,2 & 66,7 & 99,25 & 0,75 \\
\hline 14 & Naina & 53,8 & 54,1 & 99,45 & 0,55 \\
\hline 15 & Kamal & 92,3 & 92,7 & 99,57 & 0,43 \\
\hline 16 & Irma & 42,2 & 42,8 & 98,60 & 1,40 \\
\hline 17 & Diara & 64,8 & 65,5 & 98,93 & 1,07 \\
\hline 18 & Wanda & 58,4 & 59 & 98,98 & 1,02 \\
\hline 19 & Rafai & 56 & 56,6 & 98,94 & 1,06 \\
\hline 20 & Afdali & 62,2 & 62,6 & 99,36 & 0,64 \\
\hline \multicolumn{4}{|c|}{ Selisih rata-rata persentase keberhasilan dan error } & 99,04 & 0,96 \\
\hline
\end{tabular}

Jadi berdasarkan hasil yang didapatkan pada pengukuran yang ditunjukkan pada Tabel 4, maka diperoleh grafik data seperti pada Gambar 12. 


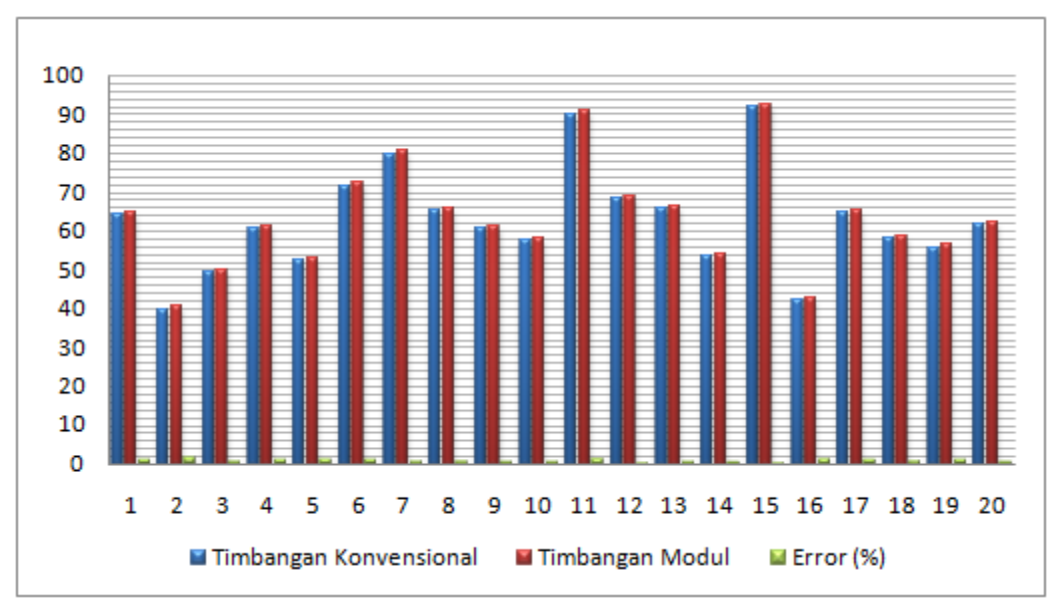

Gambar 12. Grafik hasil pengukuran berat badan

\subsection{Pengujian Sistem Penampil Suara}

Sistem penampil suara terdiri dari Arduino (sebagai pengendali), IC ISD1760, dan speaker. Sistem ini bekerja mengeluarkan informasi suara sesuai dengan kondisi berat badan. Sebelumnya, suara tersebut terlebih dahulu direkam dan disimpan dalam ISD. Pengujian sistem penampil suara ini dimaksudkan untuk menguji kinerja sistem dalam menampilkan suara secara tepat sesuai dengan kondisi berat badan pengguna. Data hasil pengujian ini ditunjukkan dalam Tabel 5 berikut ini.

Tabel 5. Pengujian sistem penampil suara

\begin{tabular}{|c|l|c|c|l|c|}
\hline No. & Nama & $\begin{array}{c}\text { BB } \\
\text { modul } \\
(\mathbf{k g})\end{array}$ & $\begin{array}{c}\text { TB } \\
\text { modul } \\
(\mathbf{c m})\end{array}$ & $\begin{array}{c}\text { Pesan suara ISD } \\
\text { (kondisi berat badan) }\end{array}$ & $\begin{array}{c}\text { IMT } \\
\text { (persamaan 1) }\end{array}$ \\
\hline 1 & Zaki & 65,2 & 160 & Berat Badan Anda Ideal & 25,47 \\
\hline 2 & Rizki & 40,7 & 158 & Berat Badan Anda Kurus & 16,30 \\
\hline 3 & Sri & 50 & 152 & Berat Badan Anda Ideal & 21,64 \\
\hline 4 & Ayu & 61,4 & 150 & Berat Badan Anda Gemuk & 27,29 \\
\hline 5 & Mira & 53,2 & 156 & Berat Badan Anda Ideal & 21,86 \\
\hline 6 & Fatin & 72,6 & 150 & Berat Badan Anda Gemuk & 32,27 \\
\hline 7 & Ikhsan & 80,8 & 160 & Berat Badan Anda Gemuk & 31,56 \\
\hline 8 & Shakir & 66,3 & 165 & Berat Badan Anda Ideal & 24,35 \\
\hline 9 & Shadri & 61,3 & 171 & Berat Badan Anda Kurus & 20,96 \\
\hline 10 & Maulana & 58,1 & 168 & Berat Badan Anda Kurus & 20,59 \\
\hline 11 & Imam & 91,4 & 159 & Berat Badan Anda Gemuk & 36,15 \\
\hline 12 & Ali & 69,1 & 164 & Berat Badan Anda Gemuk & 25,69 \\
\hline 13 & Maulid & 66,7 & 171 & Berat Badan Anda Ideal & 22,81 \\
\hline 14 & Naina & 54,1 & 149 & Berat Badan Anda Ideal & 24,37 \\
\hline 15 & Kamal & 92,7 & 168 & Berat Badan Anda Gemuk & 32,84 \\
\hline 16 & Irma & 42,8 & 149 & Berat Badan Anda Kurus & 19,28 \\
\hline 17 & Diara & 65,5 & 154 & Berat Badan Anda Gemuk & 27,62 \\
\hline 18 & Wanda & 59 & 159 & Berat Badan Anda Ideal & 24,88 \\
\hline 19 & Rafai & 56,6 & 149 & Berat Badan Anda Gemuk & 25,49 \\
\hline 20 & Afdali & 62,6 & 166 & Berat Badan Anda Ideal & 22,72 \\
\hline
\end{tabular}

\subsection{Pengujian Keseluruhan Sistem}

Pengujian secara keseluruhan sistem ini bermaksud untuk melihat hasil dari masing-masing subsistem setelah diintegrasikan. Pengujian pada proses ini dilakukan untuk melihat hasil 
keluaran secara keseluruhan dari sistem yang telah dirancang dan direalisasikan. Hasil pengujian tersebut ditunjukkan pada Tabel 6 berikut ini.

Tabel 6. Pengujian keseluruhan sistem

\begin{tabular}{|c|l|c|c|c|l|c|}
\hline No. & Nama & $\begin{array}{c}\text { BB } \\
\text { modul } \\
(\mathbf{k g})\end{array}$ & $\begin{array}{c}\text { TB } \\
\text { modul } \\
(\mathbf{c m})\end{array}$ & $\begin{array}{c}\text { Rule (BBI) } \\
\text { modul }(\mathbf{k g})\end{array}$ & $\begin{array}{c}\text { Suara ISD } \\
\text { (kondisi berat badan ) }\end{array}$ & $\begin{array}{c}\text { IMT } \\
\text { (persamaan 1) }\end{array}$ \\
\hline 1 & Zaki & 65,2 & 160 & $46-64$ & Berat Badan Anda Ideal & 25,47 \\
\hline 2 & Rizki & 40,7 & 158 & $44-62$ & Berat Badan Anda Kurus & 21,23 \\
\hline 3 & Sri & 50 & 152 & $41-57$ & Berat Badan Anda Ideal & 21,64 \\
\hline 4 & Ayu & 61,4 & 150 & $40-56$ & Berat Badan Anda Gemuk & 27,29 \\
\hline 5 & Mira & 53,2 & 156 & $43-60$ & Berat Badan Anda Ideal & 21,86 \\
\hline 6 & Fatin & 72,6 & 150 & $40-56$ & Berat Badan Anda Gemuk & 32,27 \\
\hline 7 & Ikhsan & 80,8 & 160 & $46-64$ & Berat Badan Anda Gemuk & 31,56 \\
\hline 8 & Shakir & 66,3 & 165 & $49-68$ & Berat Badan Anda Ideal & 24,35 \\
\hline 9 & Shadri & 61,3 & 171 & $52-73$ & Berat Badan Anda Kurus & 20,96 \\
\hline 10 & Maulana & 58,1 & 168 & $50-70$ & Berat Badan Anda Kurus & 20,59 \\
\hline 11 & Imam & 91,4 & 159 & $45-63$ & Berat Badan Anda Gemuk & 36,15 \\
\hline 12 & Ali & 69,1 & 164 & $48-67$ & Berat Badan Anda Gemuk & 25,69 \\
\hline 13 & Maulid & 66,7 & 171 & $52-73$ & Berat Badan Anda Ideal & 22,81 \\
\hline 14 & Naina & 54,1 & 149 & $39-55$ & Berat Badan Anda Ideal & 24,37 \\
\hline 15 & Kamal & 92,7 & 168 & $50-70$ & Berat Badan Anda Gemuk & 32,84 \\
\hline 16 & Irma & 42,8 & 149 & $39-55$ & Berat Badan Anda Kurus & 19,28 \\
\hline 17 & Diara & 65,5 & 154 & $42-59$ & Berat Badan Anda Gemuk & 27,62 \\
\hline 18 & Wanda & 59 & 159 & $45-59$ & Berat Badan Anda Ideal & 24,88 \\
\hline 19 & Rafai & 56,6 & 149 & $39-55$ & Berat Badan Anda Gemuk & 25,49 \\
\hline 20 & Afdali & 62,6 & 166 & $49-68$ & Berat Badan Anda Ideal & 22,72 \\
\hline
\end{tabular}

Pada Tabel 6 ditampilkan hasil pengujian (keluaran) secara keseluruhan dari pembacaan sensor, dimana pada urutan pertama menghasilkan nilai BB $65.2 \mathrm{~kg}$ dan TB $160 \mathrm{~cm}$. Maka perhitungan pembuktian IMT dan BBI berdasarkan persamaan 1 - 3 adalah sebagai berikut:

$$
\begin{aligned}
& I M T=\frac{B B}{(T B)^{2}} \\
& =\frac{62,6}{(1,66)^{2}}=22,72 \\
& \begin{aligned}
B A B & =18 \times(T B)^{2} \\
& =18 \times(1.6)^{2}=46,08 \mathrm{~kg}
\end{aligned} \\
& B A A=25 x \mathrm{~TB}^{2} \\
& =25 x(1.6)^{2}=64 \mathrm{~kg}
\end{aligned}
$$

Pengujian keseluruhan sistem ini berupa pengujian terhadap perangkat lunak dan konektivitas antara perangkat lunak dengan perangkat keras. Pengujian keseluruhan sistem dilakukan dengan 20 orang pemakai yang berbeda dimana untuk setiap orang dilakukan satu kali pengukuran. Dengan menganalisis hasil pengujian yang disajikan dalam Tabel 6, maka diperoleh kinerja sistem sebagai berikut. Tingkat keberhasilan rata-rata pada pengukuran tinggi badan adalah $96,80 \%$, atau dengan kata lain tingkat kesalahan rata-ratanya sebesar $3,20 \%$. Tingkat keberhasilan rata-rata pada pengukuran berat badan adalah 99,04\% atau dengan kata lain tingkat kesalahan rata-ratanya sebesar 0,64\%. Adapun tingkat keberhasilan penampilan output suara adalah sekitar $95 \%$.

Dengan demikian, maka sesuai dengan kriteria yang ditetapkan dalam Tabel 2, dapat dinyatakan bahwa sistem pengukuran tinggi badan telah bekerja sangat baik, sistem pengukuran berat badan juga telah bekerja sangat baik, dan sistem penampil suara juga telah bekerja sangat baik. Sehingga alat ukur digital untuk tinggi badan dan berat badan yang dirancang dan direalisasikan ini dapat dinyatakan telah bekerja sangat baik. 


\section{KESIMPULAN}

Berdasarkan perancangan, realisasi, dan hasil pengujian sistem yang telah dilakukan, maka dari penelitian ini dapat disimpulkan sebagai berikut:

1. Alat ukur digital untuk tinggi badan dan berat badan dengan output suara telah berhasil dirancang dan direalisasikan serta dapat bekerja dengan sangat baik. Nilai persentase keberhasilan rata-rata pada pengukuran tinggi badan adalah sebesar 96,80\%, persentase keberhasilan rata-rata pada pengukuran berat badan adalah sebesar $99,04 \%$, dan tingkat keberhasilan penampilan informasi suara adalah sebesar $95 \%$.

2. Pengguna dapat memperoleh hasil pengukuran tinggi badan dan berat badan sekaligus informasi ideal atau tidaknya berat badan tersebut serta interval nilai berat badan yang ideal.

3. Dengan adanya ouput suara di samping tampilan LCD, akan memberikan kemudahan bagi para pengguna.

\section{DAFTAR RUJUKAN}

Thomas, Johan K.W, dan Henhy (2015). Sistem Pengukur Berat dan Tinggi Badan Menggunakan Mikrokontroler AT89S51. Jurnal Tesla. 10(2).

Khoiruddin, A. M. (2015). Pengembangan Alat Ukur Tinggi Badan dan Berat Badan Digital Yang Terintegrasi. Tugas Akhir. Universitas Negeri Yogyakarta.

Fadli (2013). Rancang Bangun Alat Ukur Tinggi dan Berat Badan Berbasis Mikrokontroler (Hardware). Tugas Akhir. Politeknik Negeri Lhokseumawe.

Erlita, N., (2015). Aplikasi Alat Ukur Tubuh Digital Menggunakan Metode Fuzzy Logic Untuk Menentukan Kondisi Ideal Badan dengan Tampilan LCD dan Output Suara Untuk Tunanetra. Tugas Akhir. Universitas Jember.

Benny dan R. Zahora. (2011). Aplikasi Penentuan Posisi Busway dengan Tampilan Teks Berjalan dan Suara Berbasis IC Information Storage Device. Jurnal IImiah Elite Elektro. 2(1).

Utama, M.R., S. Rhenza, dan Rachmansyah. (2008). Alat Ukur Tinggi dan Berat Badan Digital Berbasis Mikrokontroler. Jurnal Teknik Elektro. 18(7).

Nuryanto, R. (2015). Pengukur Berat dan Tinggi Badan Ideal Berbasis Arduino. Karya Ilmiah Program Sarjana. Universitas Muhammadiyah Surakarta.

Khakim, A. L. (2015). Rancang Bangun Alat Timbang Digital Berbasis AVR Tipe Atmega32. Tugas Akhir. Universitas Negeri Semarang. 